\title{
MONOPOLY GAME AS ANDROID-BASED DENTAL HEALTH EDUCATION MEDIA
}

\author{
Bedjo Santoso $^{1)}$, M. Choiroel Anwar ${ }^{2)}$, Muliadi ${ }^{3)}$ \\ Email : bedjosantoso27@gmail.com
}

\begin{abstract}
Background: The problem of dental hygiene and many encounter is dental caries and periodontal disease. These problems can be prevented through the dental health education.

Literatur this review aims to generate dental health education media in the form of an application-based games to android

Method: Research and Development/(R\&D) and quasi experimental non-randomized control group pretes and post-test design (non-equivalent control group).

The result: a test of wilcoxon test on the main field shows the difference between the value of the knowledge and attitude of intervention and control group is Z:-Sig: 6.006 value 0.000 and Z: $863-4$, with a value of Sig: 0.000 (value of knowledge), Z:-value of 6.412 Sig: 0.000 and Z:- 4.558 value Sig: 0.000 (attitude). Mannwhitney test showed the value of the difference between knowledge and attitudes of the intervention group and the control i.e. z:4.868 with value Sig: 0.000 and value Z: 4.641 -value Sig: 0.000 .

Conclusion: the Game monopoly and leaflets as a dental health education media were equally effective in increasing knowledge and attitude of dental health. However, the game monopoly is more effective than leaflets.
\end{abstract}

Keywords: research and development, dental health Education, educational games, interactive multimedia, gaming monopoly dental health.

1) Poltekkes Kemenkes Semarang 


\section{PENDAHULUAN}

Kesehatan gigi dan mulut walaupun tidak menimbulkan kematian tetapi dapat menurunkan produktivitas kerja, bahkan berpengaruh terhadap kualitas hidup $^{1,2}$. Hal tersebut dibuktikan melalui hasil survei sosial ekonomi nasional (SUSENAS) yang menunjukkan bahwa $62,4 \%$ penduduk merasa terganggu bekerja/sekolah karena sakit gigi dengan rerata 3,86 hari $^{3}$.

Data survey menunjukan angka DMF-T di Indonesia termasuk dalam kategori tinggi bila dibandingkan dengan target WHO bahwa rata-rata Indeks DMF$\mathrm{T}$ kurang $\leq 1^{4,5}$. Faktor-faktor yang mempengaruhi timbulnya masalah kesehatan gigi dan mulut adalah keturunan, lingkungan, perilaku, dan pelayanan kesehatan gigi $^{6}$. Timbulnya masalah kesehatan gigi dan mulut dalam masyarakat adalah rendahnya perilaku pelihara kebersihan gigi dan mulut ${ }^{6}$.

Pengetahuan, sikap dan tindakan merupakan faktor yang mempengaruhi kesadaran seseorang dalam memelihara kesehatan gigi dan mulut. Hal ini sesuai dengan pendapat Nurfalah (2014) yang mengatakan bahwa terdapat hubungan signifikan antara tingkat pengetahuan kesehatan gigi dan mulut dengan kejadian karies gigi ${ }^{7}$.

Peningkatan pengetahuan, sikap dan keterampilan pemeliharaan kebersihan gigi dan mulut dapat dilakukan melalui pendidikan kesehatan gigi yang merupakan bentuk pendekatan perilaku promosi kesehatan yang membutuhkan proses pendidikan. Ketercapaian suatu proses pendidikan kesehatan gigi dan mulut ditunjukkan dengan adanya perubahan tingkah laku yang lebih baik dimana menyangkut perubahan, pengetahuan (kognitif), keterampilan (psikomotor), maupun yang menyangkut sikap dan perilaku kesehatan gigi dan mulut (afektif) Hal tersebut sesuai dengan pendapat Hamalik (1990) yang mengatakan bahwa hasil kegiatan belajar adalah perubahan tingkah laku yang berupa aspek afektif, kognitif, maupun psikomotor. Proses pendidikan dipengaruhi oleh beberapa faktor antara lain, pendidik, peserta didik, lingkungan, metode pendidikan, serta media pembelajaran $^{8}$.

Media merupakan salah satu faktor yang dapat mempengaruhi proses pendidikan kesehatan, karena merupakan alat bantu untuk mempermudah dalam penyampaian materi, sama halnya dengan media pendidikan kesehatan gigi dan mulut sebagai alat bantu belajar yang harus dikemas dengan baik, menarik dan melibatkan banyak indera agar lebih mudah di ingat. Efektivitas dan efisiensi proses pendidikan kesehatan gigi dan mulut dipengaruhi ketepatan dan kesesuaian penggunaan metode dan media pembelajaran, karena media yang digunakan tidak hanya memberikan informasi saja, tetapi harus juga memberikan pengalaman ${ }^{6,9}$

Hal tersebut didukung oleh teori Kerucut Pengalaman Dale, yaitu proses pendidikan dengan melibatkan lebih banyak indera akan lebih mudah diterima dan diingat oleh para sasaran pendidikan. ${ }^{10}$ Proses pendidikan yang banyak melibatkan indera adalah Proses pendidikan yang menggunakan media dalam bentuk permaianan. Salah satu permainan menarik yang sering digunakan sebagai media pendidikan adalah monopoli. Monopolymerupakan suatu permainan papan (board game) dengan pemainnya berlomba untuk mengumpulkan kekayaan melalui aturan permainan ${ }^{11}$.

Keunggulan permainan monopoly yaitu memiliki banyak komponen permainan yang dapat digunakan sebagai tempat untuk memasukkan konsep-konsep pengetahuan dan sikap kesehatan gigi yang akan dikenalkan kepada peserta 
didik sehingga dapat di jadikan media permaianan yang inovatif, kreatif dan menarik. Dalam dunia pendidikan anakanak, sudah banyak sekali penggunaan media permainan dalam pembelajaran antara lain monopoly (permainan papan $)^{12}$. Menurut Syahsiyah (2008), monopolymerupakan permaianan papan yang menarik dan paling terkenal di dunia karena disukai anak-anak bahkan orang dewasa sehingga sering digunakan sebagai media pembelajaran ${ }^{13}$. Selain keunggulan, permainan monopolymemiliki kelemahan tidak ramah lingkungan karena menggunakan kertas dan di dalam penerapan permainan perlu seseorang untuk mengarahkan aturan permainan. ${ }^{14}$ Untuk mengatasi kelemahan tersebut ialah dengan memanfaatkan teknologi, yang dikemas dalam bentuk aplikasi game berbasis android sehingga tidak memerlukan kertas dan seseorang untuk pengarah karena telah terprogram dalam sistem aplikasi game.

\section{METODE PENELITIAN}

Metode penelitan yang digunakan adalah Research and Development/ (R\&D) dengan tujuan untuk mengembangkan media pendidikan kesehatan gigi dan mulut berupa aplikasi game monopoly kesehatan gigi dan mulut berbasis android dengan langkah-langkah 1) studi pendahuluan (penelitian lapangan, penilitan produk yang telah ada dan kajian pustaka, 2) Perencanaan (merancang flowchart, story board dan penyusuan teks, 3) Pembuatan produk, 4) pengembangan produk yaitu uji internal (validasi ahli) dan uji eksternal (uji lapangan awal dan utama) 5) Revisi produk, 6) Produk akhir.

Instrumen penelitian berupa kuesioner dan angket. Variabel dependent yaitu pengetahuan dan sikap diukur dengan kuesioner sedangkan kelayakan media diukur dengan angket.
Desain Uji lapangan awal adalah Pre eksperiment one group pre-test postes yang dilakukan dengan besaran sampel 15 orang sesuai besaran sampel yang disarankan oleh Borg and Gall (1989) pada penelitan R\&D yaitu uji lapangan awal sebaiknya dilakukan pada 1 sampai 3 sekolah dengan jumlah responden antara 10 sampai 30.15 Peneliti memilih sampel sebanyak 15 siswa kelas IV karena didalam penelitian metode eksperimental, sampel minimal adalah 15 subjek per kelompok 16

Uji lapangan utma dilakukan pada 4 Sekolah Dasar, dengan total sampling dengan quasi-experimental non randomized control group pretes and posttest design (non equivalent control group) yang membagi kelompok menjadi dua yaitu kelompok kontrol dan kelompok intervensi. 2 Sekolah Dasar sebagai kelompok intervensi dan 2 Sekolah Dasar sebagai kelompok kontrol. Aplikasi game monopoly kesehatan gigi pada uji lapangan utama akan dimainkan sebanyak 6 kali.

\section{HASIL DAN PEMBAHASAN}

Berdasarkan hasil studi lapangan melalui wawancara kepada guru SD $\mathrm{N}$ Ngesrep 01 Kota Semarang yang dilakukan pada tanggal 12-14 Maret 2018 didapat analisis sebagai berikut :

A. Penelitian lapangan

1. Analisis metode dan media

Metode pendidikan kesehatan gigi yang sering diberikan oleh perawat gigi Puskesmas bersifat one way method dengan menggunakan media berupa poster, buklet, leaflet, flip chart

2. Analisis karakteristik siswa

Temuan karakteristik Anak Sekolah Dasar secara umum adalah masih senang bermain, senang bekerja dalam kelompok, senang berkompetitif serta senang merasakan/ melakukan sesuatu secara langsung. 
3. Penelitian produk yang telah ada

Berdasarkan hasil penelitian produk yang telah ada melalui wawancara terhadap mahasiswa Ilmu dan Teknologi UDINUS pada tanggal 15 Maret 2018 didapat informasi mengenai Game Monopoly berbasis mobile sebagai berikut :

a. Game Monopoly 3D online seperti Get rich dan Rento 3D merupakan game yang dibuat oleh satu perusahaan bukan perorangan.

b. Pembuatan Game Monopoly online 3 D membutuhkan dana yang sangat besar berkisar kurang lebih ratusan juta dan membutuhkan waktu kurang lebih 1 Tahun.

c. Game Monopoly online membutuhkan server dan maintenance yang kompleks

d. Game Monopoly online Membutuhkan tambahan dana untuk membayar server perbulan

Informasi yang didapat dari mahasiswa IT UDINUS mengenai Game Monopoly online 3D telah dipastikan dengan megunjungi perusahaan software yang ada di kecamatan Banyumanik yaitu Crocodik dan Izzaweb pernyataannya hampir sama

\section{B. Uji internal}

Tahap uji internal dilakukan dengan validator ahli yang berjumlah 3 orang yaitu Farid Ahmadi, S.Kom, M.Kom, P.hD sebagai Ahli IT (Dosen FIP UNNES), Agus Triarso, S.Kom, M.Pd sebagai Ahli media (kasi percancangan model pada BPMK KEMENDIKBUD) dan Dr. drg. Diyah Fatmasari, MDSc sebagai Ahli keilmuan (Dosen Program Pascasarjana Magister Terapan Kesehatan Poltekkes Kemenkes Semarang). Validasi ini dilakukan untuk memperoleh data yang digunakan sebagai dasar untuk merevisi produk media yang dikembangkan berupa game monopoly kesehatan gigi berbasis android.

1. Pembahasan

A. Tahap Studi Pendahuluan

1) Penelitian Lapangan

a. Analisis metode dan media

One way method merupakan metode yang sering digunakan dalam pendidikan kesehatan gigi. Metode ini kurang cocok untuk anak Sekolah Dasar dikarenakan kurang menarik dan dapat menimbulkan kebosanan dalam belajar. Tingkat keberhasilan metode didaktif sulit dievaluasi karena peserta didik bersifat pasif dan hanya pendidik yang aktif ${ }^{9}$.

Poster, leaflet, plipchart merupakan media yang sering digunakan dalam pendidikan kesehatan gigi di Sekolah Dasar. Media tersebut mulai dianggap kurang menarik karena perkembangan zaman sehingga perlu pengembangan media pendidikan kesehatan gigi yang menarik dan memanfaatkan ilmu teknologi. Hal ini sesuai pendapat yang menyatakan pemberian pendidikan kesehatan akan terlihat menarik jika disampaikan dengan media yang menarik pula. ${ }^{17}$ Pendapat lain juga mengatakan bahwa pembelajaran yang cocok dalam perkembangan teknologi di dunia pendidikan adalah menggunkan media pembeljaaran interaktif ${ }^{18}$.

Multimedia interaktif adalah alat yang dapat menciptakan penyuluhan interaktif yang mengkombinasikan teks, gambar, animasi, audio, video dan permainan. Menciptakan multimedia interaktif dalam pembelajaran harus memperhatikan beberapa hal, yaitu: a) memiliki lebih dari satu media yang konvergen, seperti menggabungkan unsur audio dan visual, b) bersifat interaktif, dalam pengertian memiliki kemampuan untuk mengakomodasi 
respon pengguna, c) bersifat mandiri atau memberi kemudahan kepada pengguna ${ }^{19}$.

\section{b. Analisis Karakteristik Siwa}

Temuan karakteristik Anak

Sekolah Dasar secara umum adalah masih senang bermain, senang bekerja dalam kelompok, senang berkompetitif serta senang merasakan/ melakukan sesuatu secara langsung. Anak sekolah dasar mempunyai beberapa sifat khas sebagai berikut : 1) adanya minat terhadap kehidupan praktis sehari-hari yang kongkrit, 2) amat realistik, ingin tahu dan ingin belajar, 3) menjelang masa akhir sekolah telah muncul minat terhadap hal-hal atau mata pelajaran khusus, 4) umumnya anak menghadapi tugas-tugasnya dengan bebas dan berusaha menyelesaikan sendiri, 5) pada masa ini anak memandang nilai (angka rapor) sebagai ukuran yang tepat mengenai prestasi sekolah, (6) anak pada masa ini gemar membentuk kelompok sebaya, biasanya untuk bermain bersama-sama ${ }^{20}$.

2) Penelitian Produk Yang Telah Ada

Hasil Penilitian produk yang telah ada menunjukkan jenis aplikasi yang cocok untuk kondisi peneliti adalah Game Monopoly offline 2D yang dalam pembuatannya tidak membutuhkan begitu banyak dana dan waktu.

\section{B. Tahap Perencanaan Desain}

Rancangan desain media game monopoly kesehatan gigi telah dihasilkan melaui proses studi pendahuluan atau analisis kebutuhan yang terdiri dari penelitian lapangan, studi literature dan penilitan produk yang telah ada. Desain ini sangat sesuai dengan sasaran karena disusun bukan berdasarkan kesenangan pribadi tapi berdasarkan karakteristik siswa dan kebutuhan spesifik siswa baik dari kebermanfaatan materi, tampilan media, serta sumber belajar siswa. Hal ini sesuai dengan pertimbangan dalam pembuatan multimedia interaktif yang tidak didasarkan atas kesenangan pribadi $^{21}$. Media promosi kesehatan yang baik adalah mampu memberikan informasi atau pesan kesehatan kepada penerima yang sesuai dengan tingkatan sehingga penerima mampu meggubah perilaku yang sesuai dengan pesan yang disampaikan $^{22}$.

C. Uji Internal

Pengembangan media pendidikan kesehatan gigi yaitu game monopoly kesehatan gigi berbasis android telah melaui proses studi pendahualuan untuk menganalisis kebutuhan sasaran dan telah melalui bebe-rapa tahap uji kelayakan atau validasi seperti validasi oleh ahli materi, ahli media, ahli teknologi, dan juga siswa di uji eksternal sebagai bahan perbaikan media.

Nilai skor kelayakan game monopoly sebagai media pendidikan kesehatan gigi berbasis android diberikan validator ahli rata-rata sebesar 82,62\% dengan kategori sangat layak (tanpa revisi). Proses validasi ahli penting dilakukan didalam proses pengembangan produk atau media, hal ini sesuai dengan pendapat para ahli yang menyatakan uji validasi ahli dan uji lapangan secara terbatas perlu dilakukan untuk menghasilkan produk yang bermanfaat dalam peningkatan kualitas pendidikan. ${ }^{23}$ Berdasarkan pendapat tersebut game monopoly sebagai media pendidikan kesehatan gigi telah layak di terapkan kepada siswa didalam uji exsternal

D. Uji Lapangan Awal

Hasil uji lapangan awal menunjukkan rata-rata pengetahuan dan sikap kesehatan gigi meningkat setelah diberikan intervensi yaitu 8,33 dan 8,20 menjadi 9,67 dan 9,47. Sebelum intervensi hanya $46,7 \%$ dan $60 \%$ yang mendapatkan nilai tertinggi yaitu 9 pada 
pre-test pengetahuan dan sikap kesehatan gigi, tetapi setelah diberi intervensi nilai keduanya meningkat menjadi 10 sebesar $66,7 \%$ dan $60 \%$. Peningkatan ini belum dapat dipastikan jika belum diuji selisih dengan menggunakan uji alternatif tberpasangan (Wilcoxon Signed Rank) karena data nilai tersebut tidak berdistribusi normal yaitu nilai sig pengetahuan dan sikap kesehatan gigi sebelum intervensi 0,002 dan 0,00 dan setelah intervensi 0,000 dan 0,000. Hasil yang diperoleh menunjukkan nilai pengetahuan dan sikap kesehatan gigi tidak memiliki negative rank, tiesnya hanya 1 , positive rank ada 14 dengan mean rank sebesar 7,50 dan hasil antara pengukuran pengetahuan dan sikap sebelum dan setelah diberikan intervensi aplikasi game monopoly kesehatan gigi berbasis android memiliki nilai $\mathrm{Z}=-3,397$ dengan nilai $\operatorname{Sig}=0,001$ dan nilai $\mathrm{Z}=$ 3,443 dengan nilai $\mathrm{Sig}=0,001$ yang artinya terdapat perbedaan signifikan antara sebelum dan sesudah intervensi yaitu $\mathrm{Sig}<0,05$ atau game monopoly sebagai media pendidikan kesehatan gigi berbasis android berpengaruh dalam peningkatan pengetahuan dan sikap kesehatan gigi anak Sekolah Dasar. Selain itu, game monopoly kesehatan gigi layak sebagai media pendidikan kesehatan gigi berdasarkan hasil angket respon siswa yang menunjukkan $73,3 \%$ siswa memberikan penilaian sangat layak (tanpa revisi) dan memberikan komentar positif terhadap media "Game monopoly kesehatan giginya bagus, menarik, seru, mudah dipahami, menambah pengetahuan dan saya ingin mendownloadnya di playstore"

Permainan adalah metode pembelajaran yang diinginkan, karena permainan dapat membuat belajar lebih menghibur dan telah banyak digunakan oleh siswa serta guru di semua kelompok usia dalam bidang pendidikan ${ }^{24-26}$. Didalam bidang pendidikan kesehatan gigi juga perlu penggunaan metode permainan guna meningkatkan semangat siswa untuk mengetahui perilaku yang baik dan yang buruk dalam kesehatan gigi serta membantu membangun kepercayaan diri dalam menjaga kesehatan gigi dan mulut.

E. Uji Lapangan Utama

Hasil uji statistik menggunakan Wilcoxon signated rank menunjukkan adanya perbedaan signifikan antara hasil pengukuran pengetahuan dan sikap kesehatan gigi kelompok intervensi sebelum dan setelah diberikan aplikasi game monopoly kesehatan gigi berbasis android dengan nilai $\mathrm{Z}=-6.006, \mathrm{Sig}=$ 0,00 dan $Z=-6.412$, Sig $=0,00($ Sig < $0,05)$ dengan peningkatan rata-rata nilai pengetahuan dan sikap kesehatan gigi sebesar 23,00 sebanyak 45 siswa dan 26,00 sebanyak 51 siswa. Hasil tersebut menunjukkan bahwa terdapat pengaruh media pendidikan kesehatan gigi yaitu aplikasi game monopoly kesehatan gigi berbasis android terhadap peningkatan pengetahuan dan sikap kesehatan gigi pada kelompok intervensi.

Uji Wilcoxon signated rank pada kelompok kontrol juga menunjukkan adanya perbedaan signifikan antara hasil pengukuran pengetahuan dan sikap kesehatan gigi sebelum dan setelah diberikan lealflet kesehatan gigi dengan nilai $\mathrm{Z}=-4,863$, Sig $=0,00$ dan $\mathrm{Z}=-$ 64,558, $\operatorname{Sig}=0,00($ Sig $<0,05)$ dengan peningkatan rata-rata nilai pengetahuan dan sikap kesehatan gigi sebesar 15,59 sebanyak 29 siswa dan 15,60 sebanyak 530 siswa. Hasil tersebut menunjukkan bahwa terdapat pengaruh leaflet kesehatan gigi terhadap peningkatan pengetahuan dan sikap kesehatan gigi pada kelompok kontrol. Hasil ini sejalan dengan penelitian lain yang menunjukkan media leaflet efektif dalam menigkatkan pengetahuan kesehatan gigi dengan diberi selebaran dan diminta untuk membacanya atau pun tidak dibandingkan dengan tidak 
diberi selebaran tetapi diberikan secara lisan pada pasien yang hadir di klinik gigi setempat. ${ }^{27}$

Hasil uji Mann-Whitney pada uji lapangan utama menunjukkan tidak adanya perbedaan yang signifikan nilai antara pre-test pengetahuan dan sikap kesehatan gigi kelompok intervensi dan kontrol dengan nilai $\mathrm{Z}=-1,508$, Sig $=$ 0,132 dan nilai $Z=-1,79$, Sig $=0,280$ sehingga antar kedua kelompok dapat dikatakan sama dan layak untuk di bandingkan nilai post-testnya setelah diberikan intervensi.

Game monopoly kesehatan gigi berbasis android dan leaflet sama-sama dapat meningkatkan pengetahuan dan sikap kesehatan gigi siswa. Akan tetapi, peningkatan pada kelompok intervensi yang diberikan game monopoly kesehatan gigi berbasis android lebih besar dibandingkan pada kelompok kontrol yang diberikan leaflet. Perbedaan itu ditunjukkan melalui nilai rerata selisih kelompok intervensi yaitu sebesar 74,55 dan 74,33 sedangkan pada kelompok kontrol hanya sebesar 46,45 dan 46,57. Hasil uji beda dengan menggunakan Mann-whitney juga menunjukkan terdapat perbedaan yang signifikan antara nilai post-test pengetahuan dan sikap kesehatan gigi kelompok intervensi dan kelompok kontrol dengan nilai $\mathrm{Z}=-4868$, Sig = 0,000 dan $Z=-4,641$, Sig $=0,000$. Perbrdaan yang signifikan ini dikarenakan media aplikasi game memiliki kelebihan yaitu dapat menstimulasi efek gerak sehingga terlihat lebih menarik dan lebih mudah merangsang pemahaman siswa secara kognitif, afektif, psiko-motorik, dan bersifat kompetitif yang dapat menumbuh rasa ingin menang. Hal ini didukung oleh hasil penelitian yang menyebutkan bahwa penyampaian materi menggunakan multimedia interaktif dapat meningkatkan pemahaman materi yang disampaikan dibandingkan dengan pembelajaran secara konvensional ${ }^{28}$.

\section{F. Produk Akhir}

Game monopoly kesehatan gigi merupakan media pendidikan kesehatan gigi yang dibuat melalui rangkaian proses penelitian dan pengembangan dan merupakan salah satu multimedia interaktif karena mengacu pada produk dan layanan digital sistem teknologi yang merespon tindakan pengguna dengan menyajikan konten seperti teks, gambar bergerak, animasi, video, audio, dan video game. Belum tersedianya multimedia interaktif kesehatan gigi di Sekolah Dasar menjadikan game monopoly kesehatan gigi berbasis android sangat tepat digunakan sebagai media promosi kesehatan gigi baik dalam penyuluhan maupun pembelajaran mandiri. Penggunaan multimedia bertujuan untuk mendapatkan pembelajaran yang efisien dan efektif ${ }^{29}$.

Tujuan dari pengembangan media promosi kesehatan gigi dan mulut adalah untuk menghasilkan media yang mampu meningkatkan pengetahuan dan sikpa sasaran yang membacanya. Maka dari itu media ini berisikan materi penting terkait masalah kesehatan gigi yaitu pengertian kesehatan gigi dan mulut, jenis dan fungsi gigi, penyakit akibat gigi dan mulut, penyebab kerusakan gigi, upaya memelihara kesehatan gigi dan mulut, makanan yang mampu merusak gigi, cara menyikat gigi yang benar. Materi yang disajikan dalam media ini berdasarkan kajian pustaka dan beberapa jurnal yang telah dikatakan layak oleh ahli materi. Penyajian tulisan yang ditampilkan dalam materi menginterpretasikan gambar dan pemikiran yang sederhana serta materi disajikan secara menarik sehingga siswa mudah memahami dan membuat media menjadia sangat efektif ${ }^{29}$.

Melalui media ini diharapkan siswa dapat belajar secara mandiri dan mengingat materi kesehatan gigi yang ada didalamnya dalam bentuk simulasi, gambar dan suara yang sehingga 
mendukung kemampuan kognitif siswa da-lam berpikir, berperilaku, dan merubah kebiasaan hidup sehat melalui media yang disampaikan ${ }^{30}$. Game monopoly sebagai media pendidikan kesehatan gigi berbasis android juga menyajikan animasi, teks, gambar dan musik yang menarik sehingga dapat mengatasi kebosan siswa dalam belajar. Salah satu media yang efektif adalah media yang dapat mengatasi kebosanan dalam belajar ${ }^{29}$.

Setiap media mempunyai kekuatan dan kelemahan masing-masing. Kelemahan media ini adalah kurang efektif dalam meningkatkan keterampilan khususnya keterempilan cara menyikat gigi. Hal ini sesuai dengan penelitian yang menyatakan bahwa penyuluhan menggunakan media audio visual dan Penyuluhan menggunakan metode demonstrasi efektif meningkatkan pengetahuan sasaran siswa SD hal ini terlihat dari mayoritas sasaran memiliki pengetahuan menyikat gigi yang baik. Akan tetapi, secara deskriptif metode penyuluhan menggunakan demontrasi lebih efektif dibandingkat audio visual. ${ }^{31}$

\section{SIMPULAN DAN SARAN}

Berdasarkan analisis data dan hasil kegiatan validasi ahli media, ahli materi, ahli teknonlogi dan pengguna (siswa), serta hasil uji coba lapangan awal dan uji lapangan utama maka dapat dikatakan bahwa game monopoly layak dan efektif sebagai media pendidikan kesehatan gigi berbasis android dan efektif dalam meningkatan pengetahuan dan sikap kesehatan gigi di sekolah dasar khususnya pada siswa kelas IV SD N Ngesrep 1, Banyumanik 02 dan Banyumanik 04 Kota Semarang. Meskipun demikian media ini memiliki kelemahan yang sudah disebutkan di atas. Selain itu kelemahan lainnya adalah belum diketahui seberapa besar pengaruh dan efektifitas media ini terhadap peningkatan pengetahuan dan sikap kesehatan gigi di uji lapangan operasional.

\section{DAFTAR PUSTAKA}

1. Sheiham A. Oral health, general health and quality of life. Bulletin of the World Health Organization.83(9):644-.2005

2. Keboa M, Madathil S, Nicolau B. Do perceived dental treatment needs reflect objectively measured needs in children? International Journal of Pediatrics.2016

3. Statistik BP. Profil Kemiskinan di Indonesia September 2012. Sumber.28:59.2012

4. Sadeghi M, Bagherian A. DMFT index and bilateral dental caries occurance among 12-year-old students in Rafsanjan-2007. Journal of Rafsanjan university of medical sciences.7(4):26774.2008

5. Avery DR, McDonald RE. Dentistry for the child and adolescent: Mosby; 2004.

6. Notoatmodjo S. Pendidikan dan perilaku kesehatan. Jakarta: Rineka Cipta.16:1549.2003

7. Nurfalah A, Yuniarrahmah E, Aspriyanto D. Efektivitas Metode Peragaan Dan Metode Video Terhadap Pengetahuan Penyikatan Gigi Pada Anak Usia 9-12 Tahun Di Sdn Keraton 7 Martapura. Jurnal Kedokteran Gigi.144.2014

8. Hamalik O. Pengembangan Kurikulum, dasar-dasar dan Pengembangannya. Bandung: Mandar Maju.1990

9. Maulana HD, Sos S, Kes M, editors. Promosi kesehatan. 2009: EGC.

10.Dale E. Audiovisual methods in teaching. 1969

11.Jawandi A. Bimbingan Kelompok Dengan Media Permainan "Smart Monopoli” Untuk Meningkatkan Kreativitas Siswa Kelas V Sd Negeri Tumenggungan Tahun Pelajaran 2012/2013: Universitas Sebelas Maret; 2013.

12.Vikagustanti DA, Sudarmin S, Pamelasari SD. Pengembangan Media 
Pembelajaran Monopoli IPA Tema Organisasi Kehidupan Sebagai Sumber Belajar Untuk Siswa SMP. Unnes Science Education Journal.3(2).2014

13. Aryan B, Iska DN. Pengaruh penggunaan permainan monopoli sebagai media pengajaran matematika terhadap minat belajar matematika siswa Sekolah Dasar: studi eksperimen di SDIT Al-hikmah pela Mampang Kelas V pada pokok bahasan bangun datar.

14. Rohman M, Amri S. Strategi dan Desain Pengembangan Sistem Pembelajaran. Jakarta: Prestasi Pustakaraya.2013

15. Borg WR, Gall M. D.(1989). Education research.1989

16. Husein U. Riset Sumber Daya Manusia Dalam Organisasi. Edisi revisi, Gramedia, Jakarta.1999

17. Pratiwi DA, Yuniar N, Erawan PEM. Pengaruh Penyuluhan Metode Permainan Edukatif dan Metode Ceramah terhadap Pengetahuan, Sikap dan Tindakan Tentang Pencegahan Penyakit Diare pada Murid SD di Kecamatan Poasia Kota Kendari Tahun 2015. Jurnal Ilmiah Mahasiswa Kesehatan Masyarakat.1(2).2016

18. Setiawan H, Adi S, Ulfah NH. Pengembangan Multimedia Interaktif Berbasis Autoplay Sebagai Media Promosi Kesehatan Tentang Kesehatan Gigi dan Mulut pada Siswa Kelas V SDN Percobaan 02 Kota Malang. PREVENTIA.2(2).2017

19. Rahayuningrum Rh. Penggunaan Media Pembelajaran Multimedia Interaktif Berbantuan Komputer Untuk Meningkatkan Motivasi Belajar Dan Kemampuan Pemecahan Masalah Matematika Siswa Kelas Viif Di Smp Negeri 2 Imogiri. Peran Ict Untuk Mendukung Implementasi Pendidikan Karakter Dalam Pembelajaran Matematika.2011

20. Nasution N. Psikologi pendidikan. Jakarta: Departemen Pendidikan dan Kebudayaan.1992
21. Suiraoka IP, Supariasa D. Media Pendidikan Kesehatan. Yogyakarta Graha Ilmu.2012

22. Komala L, Novianti E, Subekti P, Bandung DIKFU. Strategi Pemilihan Media Promosi Kesehatan Dalam Penanggulangan Hiv/Aids Di Kabupaten Garut. Acta diurnA | Vol.10(2).2014

23. Santyasa IW, editor. Metode penelitian pengembangan dan teori pengembangan modul. Disajikan dalam Seminar Pelatihan Bagi Para Guru TK, SD, SMA, dan SMK; 2009.

24. Franklin S, Peat M, Lewis A. Nontraditional interventions to stimulate discussion: the use of games and puzzles. Journal of Biological Education.37(2):79-84.2003

25. Weisskirch RS. An analysis of instructorcreated crossword puzzles for student review. College Teaching.54(1):198-201.2006

26. Crossman EK, Crossman SM. The crossword puzzle as a teaching tool. Teaching of Psychology.10(2):98-9.1983

27. O'Neill P, Humphris G, Field E. The use of an information leaflet for patients undergoing wisdom tooth removal. British Journal of Oral and Maxillofacial Surgery.34(4):331-4.1996

28. Rizqi MB. Pengembangan media pembelajaran autoplay dan quiz creator pada mata pelajaran IPS materi penjajahan belanda untuk meningkatkan pemahaman siswa kelas V di SDI AlFaqih Baran Sukoanyar Pakis Malang: Universitas Islam Negeri Maulana Malik Ibrahim; 2015.

29. Dwiyogo WD. Media pembelajaran. Malang: Wineka Media.2013

30. Khadijah K. Pengembangan kognitif anak usia dini. Perdana Publishing; 2016.

31. Santoso B, Sutomo B. Penyuluhan Metode Audio Visual Dan Demonstrasi Terhadap Pengetahuan Menyikat Gigi Pada Anak Sekolah Dasar. Jurnal Kesehatan Gigi.3(2):53-7.2016 